\title{
Current status and future directions of traditional ecological knowledge in forest management: a review
}

\author{
by Marianne Cheveau1, Louis Imbeau¹, Pierre Drapeau² and Louis Bélanger ${ }^{3}$
}

\begin{abstract}
In the last 25 years, the number of published studies that refer to traditional ecological knowledge (TEK) has constantly increased, with now more than 200 papers published each year. The objective of this review was to determine how this knowledge is used in current forest management around the world, and how local communities are involved in forest management planning. Published papers from 1983 to 2005 relating to TEK were found using the ISI Web of Science database. Despite the growing amount of literature published on TEK, we found only 21 studies that specifically address forest management per se. In these studies, TEK integration took different paths: using traditional management rules as a framework (five studies), using value maps to adapt practices in time and space (three studies), or by a zoning process that divides the land into areas in which different land uses are emphasized (six studies). Some community involvements are "active" with co-management committees composed of stakeholders (including community members), each having a voice; some are "passive" with external managers using criteria and indicators previously developed from community values and objectives. Although important changes in mentality and firm political decisions are still required before more efficient partnership between TEK and western science is reached in forest management planning, our review showed that Canadian initiatives proposed promising processes that could ensure better TEK incorporation and improved community participation.
\end{abstract}

Key words: traditional ecological knowledge, TEK, sustainable forest management, community participation, first nations, forest management planning

\section{RÉSUMÉ}

Au cours des 25 dernières années, la quantité détudes traitant des savoirs écologiques traditionnels (SET) a constamment augmenté, atteignant maintenant plus de 200 publications par an. L'objectif de cette revue de littérature était de déterminer comment ces connaissances sont utilisées aujourd'hui pour l'aménagement forestier à travers le monde, et comment les populations locales sont impliquées dans la planification de l'aménagement forestier. Tous les articles traitant des SET, publiés entre 1983 et 2005, ont été extraits à partir de la base de données ISI Web of Science. Malgré labondance de littérature publiée sur les SET, seulement 30 études abordaient spécifiquement l’aménagement forestier comme tel. Dans ces études, l'intégration du SET pouvait prendre différentes avenues : s'inspirer des règles ancestrales de gestion (cinq études), adapter les pratiques dans le temps et l'espace en fonction des valeurs à priorizer (trois études), ou en divisant le territoire en zones à vocations différentes basées sur l'utilisation des terres (six études). L’engagement des communautés pouvait être " actif ", à travers des comités de co-gestion composés des différents utilisateurs de la forêt (incluant des membres de la communauté), chacun ayant une voix ; ou " passif » lorsque des aménagistes extérieurs utilisaient des critères et indicateurs développés à partir des valeurs et objectifs de la communauté. Cependant, d'importants changements de mentalité et des décisions politiques fermes seront encore nécessaires avant de voir une participation entière des communautés et une incorporation effective des SET et de la science occidentale dans la planification forestière. Il semble, par ailleurs, que plusieurs initiatives canadiennes présentent des processus prometteurs pour sassurer de l'incorporation des savoirs traditionnels et pour instaurer une gestion participative.

Mots-clés : savoirs écologiques traditionnels, SET, aménagement forestier durable, gestion participative, autochtones, planification de l'aménagement forestier

\footnotetext{
${ }^{1}$ Chaire CRSNG-UQAT-UQAM en Aménagement Forestier Durable, Université du Québec en Abitibi-Témiscamingue, 445 bld de l’université, Rouyn-Noranda, Québec J9X 5E4. E-mail: marianne.cheveau@uqat.ca / louis.imbeau@uqat.ca

${ }^{2}$ Département des sciences biologiques, Université du Québec à Montréal, C.P. 8888, Succ. Centre Ville, Montréal, Québec H3C 3P8. E-mail: drapeau.pierre@uqam.ca

${ }^{3}$ Faculté de foresterie et de géomatique, Pavillon Abitibi-Price, Université Laval, Québec, Québec G1K7P4. E-mail: louis.belanger@ sbf.ulaval.ca
} 


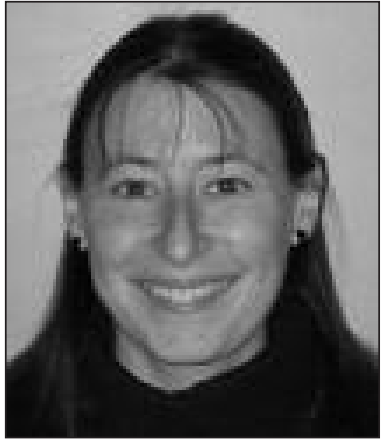

Marianne Cheveau

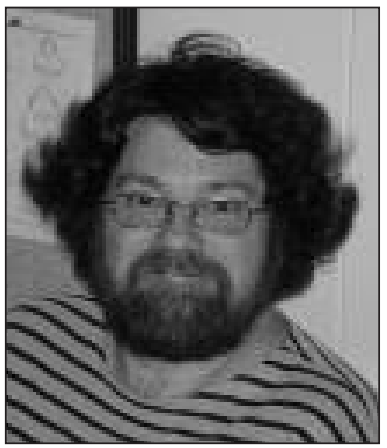

Pierre Drapeau

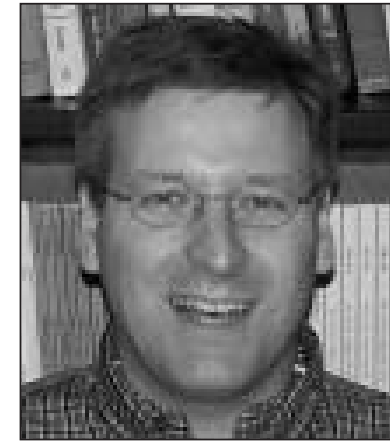

Louis Imbeau

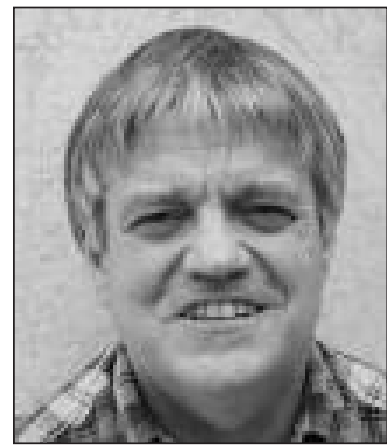

Louis Bélanger

\section{Introduction}

The use of traditional ecological knowledge (TEK) in resource and environmental management is a fairly recent development. Although this knowledge was long recognized by ethnologists, its utility and relevance to applied management appeared only in the early 1980s with the IUCN Symposium on TEK held in Indonesia in 1982 and creation of the TEK Working Group in 1984. Moreover, it is only since the publication of Our common future by the World Commission on Environment and Development (UNWCED 1987), which encouraged the use of TEK to solve problems in modern resource management, that TEK finally received its currently widely accepted international recognition (Johnson 1992).

The most commonly accepted definition of traditional ecological knowledge is as follows:

...Traditional ecological knowledge or TEK is a cumu-

lative body of knowledge and beliefs, handed down through generations by cultural transmission, about the relationship of living beings (including humans) with one another and with their environment. Further, TEK is an attribute of societies with historical continuity in resource use practices; by and large, these are non-industrial or less technologically advanced societies, many of them indigenous or tribal (Berkes 1993).

Ericksen and Woodley (2005) added that Traditional ecological knowledge may or may not be indigenous (in this case named Indigenous ecological knowledge, IEK), but in both cases has roots firmly in the past, contrary to Local knowledge (LK) which is also place-based experiential knowledge, but not necessarily old (i.e., farmers or fishermen) (Joshi et al.
2004). Otherwise, the term TEK remains controversial because it could be interpreted as old and static (Lewis 1993). On the contrary, traditional knowledge is highly dynamic and cumulative, and although based on the experience of previous generations, it is verified at each new generation, but added to and adapted to meet present socio-economic and technological changes by adaptive processes and trial-and-error learning (Johnson 1992, Baines and Hviding 1993). Tradition further implies historical continuity of culture and knowledge over many generations.

Traditional People, who could be defined as people living a subsistence lifestyle, close to nature and natural resources, have developed a nested worldview, synthesized by Berkes (1999) in the knowledge-practice-belief complex, where knowledge of the land, animals and plants is embedded in a management system with land use practices, which are sustained by social institutions, all being defined by particular ethics and beliefs. Contrary to some scientists' assumptions (Howard and Widdowson 1996), western science views on land use and resource management are also rooted in a culture and system of thought (based on reductionism, experimentation, reason and rationality); consequently, they are not completely value-free (Stevenson 1997).

These fundamentally different worldviews have been one of the major causes of conflict regarding land use and management between managers, scientists and government on one hand and traditional communities on the other hand. However, all systems of human knowledge are created by similar processes and are more alike than a focus on their apparent differences may suggest (Feit 1988). Moreover, western models of knowledge have also changed between centuries, from a dichotomy of organic and inorganic world to a vision where animals and habitat are incorporated in a complex system. When ecological theories were based on climax equilibrium and maximum sustainable yield, TEK was firstly regarded as superstition by most scientists, and consequently of no practical use for current management issues (Howard and Widdowson 1996).

Recently, new paradigms that introduce concepts like complexity, system dynamics and resilience have led scientists to widely accept new approaches such as adaptive and sustainable management (Holling 1986, Holling et al. 1998). Western scientists now encourage the preservation of ecosystem integrity, even after resource exploitation (Regier 1993), which is considered as the fundamental principle of ecosystem-based management (Hunter 1999). These approaches also include a broader view of the connections between ecosystems and societies, which encourage more public involvement, especially where Traditional Peoples are connected to the ecosystems in which they live. These new concepts appear to be reducing the distance between science and traditional ecological knowledge (Davidson-Hunt and Berkes 2001). However, if the concept of knowledge is understood with regards to how we know (instead of what we know) through peoples' relationships with their environment, and not as an objective truth, then there is a common ground to enable multiple perspectives to contribute to ecosystem management (Woodley 2005).

Traditional Peoples' ecological knowledge systems are based on survival and success in hunting, fishing, gathering and trapping, which ensure a sustainable use of resources. 
Local land use practices allow communities to remain economically and socio-culturally viable, while at the same time ensuring that there is a stable foundation for the well-being of future generations. This understanding of sustainability is notably similar to definitions expressed by the Brundtland Commission (UNWCED 1987) and Agenda 21 (UNCED 1992). The need for traditional knowledge incorporation and community involvement in resource management is recognized by the Rio Declaration, the Convention on Biodiversity and different national strategies around the world. The New Forest Code (1994, cited in Poissonnet and Lescuyer 2005) in Cameroon, the Strategy for the Involvement of communities and voluntary agencies in the Regeneration of Degraded Forests in India (1990, cited in Martin and Lemon 2001), as well as the Canadian National Forest Strategy Coalition (2003) are recent examples of this worldwide trend. In forest management, the Forest Stewardship Council (FSC) and other certification agencies especially encourage participation of indigenous communities in co-management committees to obtain sustainable forest management labels.

Sustainable forest management can be defined as maintaining and enhancing the long-term health of forest ecosystems for the benefit of all living things, both nationally and globally, while providing environmental, economic, social and cultural opportunities for the benefit of present and future generations (CCFM 2000). This definition implies respect and protection of the ecosystem per se (species and natural processes), but also its multiple uses (timber and wildlife harvesting, non-timber forest products, recreational activities, indigenous traditional activities). Because Traditional Peoples living in forest ecosystems are highly dependent on non-timber forest products (NTFP), research on these products has often been run in parallel with studies on TEK and forest management. Collectively, these studies provide a privileged arena of investigation in which ecology, TEK, and timber and NTFP harvesting can be brought together in a sustainable forest management framework (Davidson-Hunt and Berkes 2001).

Considering the recent recognition of TEK in forest resource and environmental management, how are such considerations currently integrated into forest management planning? In this paper, we propose 1) a review of case studies around the world that try to integrate TEK and that involve communities in forest planning and management, and 2) a synthesis of different processes that have been developed to promote efficient participation of communities and inclusion of their knowledge in sustainable forest management.

\section{Methods}

In this study we do not intend nor pretend to do an exhaustive review of all TEK-related work, which would include reports and unpublished theses. Our intent was specifically to review published case studies, easily available worldwide, which justify our choice to use a recognized database of peerreview papers published in scientific journals. We therefore used the ISI Web of Science online database provided by Thomson Scientific, and we generated a list of published papers from "Social Science Citation Index," "Arts and Humanities Citation Index" and "Science Citation Index (Expanded)" between 1983 and 2005 (done on January 31, 2007), which included the terms "traditional knowledge," "indigenous knowledge," "local knowledge," "environmental knowledge" or "ecological knowledge" as Title or Topic (1805 papers). These databases cover over 8700 leading journals of science, technology, social sciences, arts, and humanities. From this bibliography, we extracted articles with "forest" or "forestry" in the Title or Topic (222 papers). If we define forest management both as the planning of use and the use of the forest for any purpose (wood or NFTP harvesting, hunting, spiritual activities, etc), only 21 articles were specifically related to forest management per se. We analysed documents from Asia, Africa, South and North America, with special attention given to how TEK was collected (gathering methods) and how it was really integrated into management decisions. We also evaluated community involvement level (when possible) using Berkes' (1994) levels of co-management: (1) informing, (2) consultation, (3) co-operation, (4) communication, (5) advisory committees, (6) management board and (7) partnership of equals/community control.

There is no "universal" recognized keyword to drive our research in the database, thus some interesting papers could indeed have been missed (for example those using "community-based forest management" or "participatory forest management"). We also acknowledge that literature published in languages other than English/French were not considered in our review.

For the synthesis of different processes enhancing efficient participation of local communities in forest planning and management, we specifically analysed three Canadian initiatives, from papers published in scientific journals (Karjala and Dewhurst 2003, Karjala et al. 2004) and also pertinent chapters (Stevenson and Webb 2003, 2004) or reports (Pelletier 2002, Pelletier 2002, Stevenson 2005, Waswanipi Cree Model Forest 2007) (grey literature) not listed in the ISI Web of Science database.

\section{Results}

Since 1983,1805 papers on TEK were published according to our initial search within the ISI Web of Science database. Publishing rates have constantly increased in the last 15 years with more than 25 papers per year since 1991, 50 per year since 1995, 100 per year since 1998, and more than 200 per year since 2003 (Fig. 1). Among these contributions, 12\% (222 papers) contained forest-related issues, for example, knowledge on natural disturbances (Kovacs et al. 2004) or wildlife (Dahl 2005), medicinal plant and non-timber forest product (NTFP) uses (Pakia and Cooke 2003a, b), among others.

\section{TEK-gathering}

Nineteen of the retained 21 documents presented a case study, in which a majority (15) gathered TEK. In these studies, only two did not describe the methodology that was used to collect community knowledge or values, even if they mentioned that they created land use and occupation maps (Polansky and Heermans 2004, Sekhar 2004). Eight studies used open-ended or informal interviews to collect traditional knowledge or to gather perceptions of stakeholders involved in management committees. Six were based on group discussions, five were based on participant observations, three were based on non-participant observations, one used questionnaires, three produced value or objective maps, and finally, six 


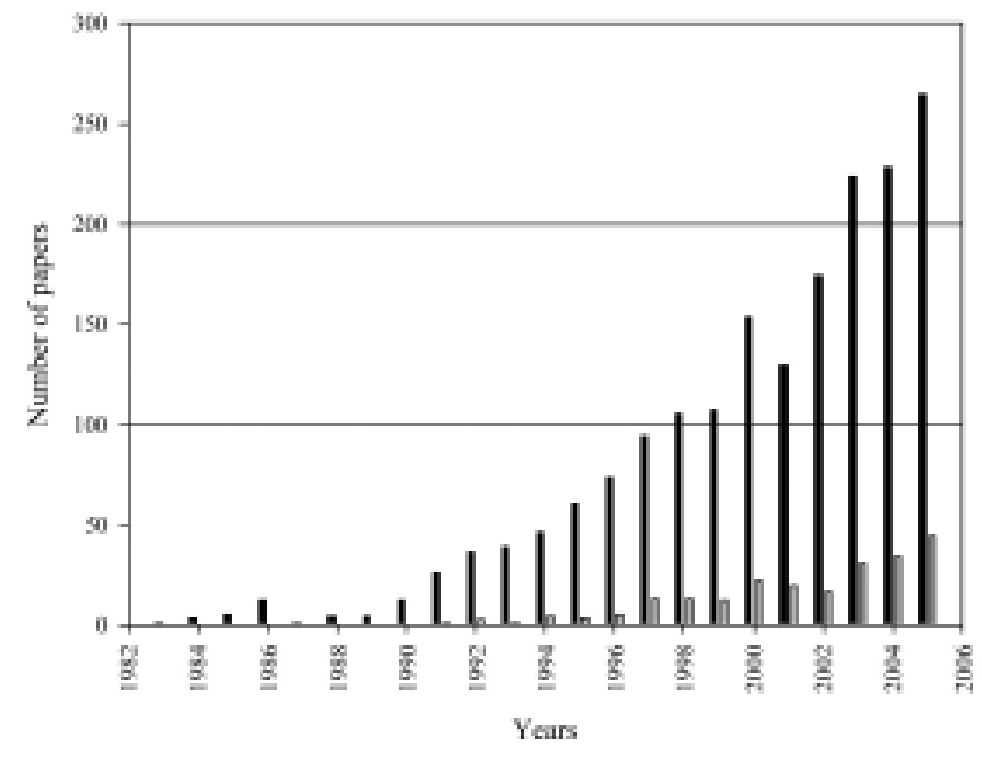

Fig. 1. Progression of the number of published papers that address the issue of traditional ecological knowledge (TEK) in peer-reviewed journals (source: Web of Science IS database). Dark grey: all papers on TEK; light grey: papers that refer to TEK in forestrelated issues.

created traditional land use and occupation maps (Table 1). Some described in detail the subjects that were tackled during discussions and interviews (Dei 1993, Wickramasinghe 1997, Karjala and Dewhurst 2003, Herrmann 2005, McCall and Minang 2005, Silvano et al. 2005), but others not at all (e.g., Sekhar 2004). Five studies also compared traditional knowledge with scientific data collected in the field (Wickramasinghe 1997, Polansky and Heermans 2004, Herrmann 2005, Robiglio and Mala 2005, Silvano et al. 2005).

In order to improve Iranian forest management plans, Ghazanfari et al. (2004) used only participant observation to document traditional management practices to increase local community acceptance. Herrmann (2005) used both participant observation and open-ended interviews to document indigenous traditional management of Araucaria araucana forests in Chile, the cultural role of this species and perceived risks linked to its exploitation (seed gathering). Moreover, he specifically discussed with participants how TEK could contribute to forest management. In Sekhar's (2004) study, the goal was to compare tree species chosen for planting by local populations in India considering religious, social and economic factors with choices made by scientific experts. She conducted non-participant observations and open-ended interviews, but did not give details on treated subjects. In Wickramasinghe's (1997) case study, group discussions and participant observation were used to document traditional use of forest resources in Sri Lanka and reasons for opposition to an integral conservation project developed after an important degradation of the local forest. In Thailand, Roth (2004) used only focus group interviews with key informants in a similar case of local opposition to a conservation park, particularly in relation to fixed geographical borders, which are not a traditional way of viewing the land. Dei (1993) studied human causes of local deforestation in Ghana using participant and non-participant observations, as well as interviews on traditional harvesting, myths and taboos related to forests, and land use for timber harvesting and agriculture. Natcher et al. (2005) used the same approach (participant and non-participant observations as well as interviews) to evaluate satisfaction of stakeholders involved in a committee for co-management of fish, wildlife and other renewable resources in Yukon (Canada). In a study documented by Silvano et al. (2005), the Brazilian government wanted to reforest grazing land, in order to protect an important river (for water supply) and create a corridor between two forest areas. The authors used a questionnaire to evaluate local perceptions on land degradation (ecological integrity of the river, water quality and forest ecosystem services). Farmers acknowledged advantages of the surrounding forest ecosystem for livestock, but they were not interested in more protection, because they did not recognize their responsibility in land degradation. Comparisons between local knowledge and scientific data have shown that, for example, farmers have underestimated the issue of water quality degradation in this river basin. This suggests that we need to be cautious and adequately verify information before using it in management strategies (Davis and Wagner 2003).

A second group of articles focused on land use or value maps as tools that should incorporate TEK. In fact, these maps are not outputs but spatial representations of TEK, traditional practices and values. Polansky and Heermans (2004) evaluated the potential use of different high-technology tools (satellite maps, aerial photos, GIS) associated with TEK to improve forest management in Zambia. From panchromatic aerial photos, simplified maps were created, in which land use information (non-timber forest products, agriculture, and zone limits) was added with the collaboration of the local population (no details concerning their methodology). Robiglio and Mala (2005) conducted a similar study in Cameroon, using GIS and TEK (collected from focus group discussions and field trips) to create traditional land use and occupation maps. Karjala and collaborators (Karjala and Dewhurst 2003, Karjala et al. 2004) carried out open-ended interviews and meetings with focus groups in order to generate land use and occupation maps including values, needs and perspectives from an indigenous community using criteria and indicators, in a context of conflict between commercial forestry and traditional rights of First Nations in British Columbia (Canada). McCall and Minang (2005) used the same approach (open-ended interviews, focus group discussions) to realize land use maps. Furthermore, they used criteria and indicators developed with the community to evaluate governance of a Cameroon communal forest. Natcher and Hickey (2002) used all available methods to realize land use maps using criteria and indicators developed with an indige- 
Table 1. Methodological approaches used to collect traditional ecological knowledge or community perceptions in reviewed studies related to forest management $(\mathrm{N}=15$ ). (Six studies were omitted because they presented no case study or no TEK-gathering.)

\begin{tabular}{|c|c|c|c|c|c|c|c|}
\hline Articles & $\begin{array}{c}\text { Open-ended } \\
\text { interview }\end{array}$ & $\begin{array}{c}\text { Group } \\
\text { discussion }\end{array}$ & Questionnaire & $\begin{array}{c}\text { Participant } \\
\text { observation }\end{array}$ & $\begin{array}{c}\text { Non- } \\
\text { participant } \\
\text { observation }\end{array}$ & $\begin{array}{l}\text { Value and } \\
\text { objective } \\
\text { map }\end{array}$ & $\begin{array}{l}\text { Land use } \\
\text { and } \\
\text { occupation } \\
\text { map }\end{array}$ \\
\hline Dei 1993 & $x$ & & & $x$ & $x$ & & \\
\hline Robinson and Ross 1997 & & & & & & & $x$ \\
\hline Wickramasinghe 1997 & & $x$ & & $x$ & & & \\
\hline McGregor 2002 & $x$ & & & & & $x$ & \\
\hline Natcher and Hickey 2002 & $x$ & $x$ & & $x$ & & & $x$ \\
\hline Karjala and Dewhurst 2003 & $x$ & & & & & $x$ & \\
\hline Ghazanfari et al. 2004 & & & & $x$ & & & \\
\hline Karjala et al. 2004 & $x$ & $x$ & & & & $x$ & \\
\hline Polansky and Heermans 2004 & & & & & & & $x$ \\
\hline Roth 2004 & & $x$ & & & & & \\
\hline Sekhar 2004 & $x$ & & & & $x$ & & \\
\hline Herrmann 2005 & $x$ & & & $x$ & & & \\
\hline McCall and Minang 2005 & $x$ & $x$ & & & & & $x$ \\
\hline Robiglio and Mala 2005 & & $x$ & & & & & $x$ \\
\hline Silvano et al. 2005 & & & $x$ & & & & $x$ \\
\hline
\end{tabular}

nous community in Alberta (Canada). Robinson and Ross (1997) proposed also to create land use maps using interviews to gather indigenous values and objectives in Alberta (Canada), with numerous validations during the process. Using open-ended interviews and priority value maps, McGregor (2002) evaluated the satisfaction level of different forest users (indigenous and non-indigenous) who participated in consultations regarding forest planning in Ontario (Canada).

\section{TEK incorporation}

Different types of information (traditional management practices, land use, and values) that are contained in TEK may be incorporated into forest management. Traditional management practices could inspire modern management (Berkes et al.2000) to reduce conflicts between stakeholders (Herrmann 2005), or simply because they have often been sustainable for thousands of years (Stevenson 1997). Five studies proposed to incorporate some traditional management rules into modern forest management plans (Wickramasinghe 1997, Ghazanfari et al. 2004, Roth 2004, Sekhar 2004, Herrmann 2005). Traditional knowledge of land use can also be helpful in creating a zoning of the landbase to share land between different users or adapt forestry practices for other uses at specific moments. Six studies proposed such an approach (Dei 1993, Robinson and Ross 1997, Natcher and Hickey 2002, Polansky and Heermans 2004, McCall and Minang 2005, Robiglio and Mala 2005). The integration of local values and objectives can also be considered as a means to involve communities in forest management, using criteria and indicators, value maps or both. This can lead to generating land use maps that incorporate spatial and temporal traditional uses. Three studies proposed this approach (McGregor 2002, Karjala and Dewhurst 2003, Karjala et al. 2004).
More than half of the studies incorporated TEK in a forest management process (Table 2). A project was aimed at establishing a new forest planning process that would incorporate TEK ultimately (Ghazanfari et al. 2004), whereas for others, the integration of TEK is already underway, although at different levels. Some studies have collected information on traditional management practices or traditional land uses, but this information is not yet or not efficiently incorporated within forest management plans, but could be so in the near future (Dei 1993, Wickramasinghe 1997, Polansky and Heermans 2004).

\section{Community involvement}

Six studies presented no community involvement in forest management (Dei 1993, Wickramasinghe 1997, Gautam and Watanabe 2002, Polansky and Heermans 2004, Herrmann 2005, Silvano et al. 2005) (Table 2). For example, Silvano et al. (2005) collected local knowledge to propose reforestation strategies, but the local community did not take part in the development of these forest management strategies. In Herrmann's (2005) study, it was not clear how TEK was incorporated into forest management, although the Chilean government encouraged the local community to reforest clearcuts with cultivated Araucaria araucana (ex situ conservation). The local community certainly was involved in conservation of this endangered species, but not really in its in situ management. In Wickramasinghe's (1997) study, the government of Sri Lanka decided to preserve a forest without accounting for local population dependence on forest resources. Thompson (1999) presented a synthesis of different pilot projects in social forestry in Indonesia, but local community involvement is not described in detail. Nevertheless, it included gathering TEK (on forest and on traditional management) and it was a participatory process. 
Table 2: TEK-gathering, incorporation, and community involvement in reviewed studies related to forest management $(\mathrm{N}=21$ ). Levels of Community involvement have been evaluated (when possible) using Berkes' (1994) levels of co-management : (1) informing, (2) consultation, (3) co-operation, (4) communication, (5) advisory committees, (6) management board and (7) partnership of equals/community control.

\begin{tabular}{|c|c|c|c|c|c|c|c|c|}
\hline Articles & Country & $\begin{array}{l}\text { Case } \\
\text { study }\end{array}$ & $\begin{array}{c}\text { TEK- } \\
\text { gathering }\end{array}$ & $\begin{array}{l}\text { Gathering } \\
\text { description }\end{array}$ & $\begin{array}{l}\text { TEK } \\
\text { incorpora- } \\
\text { tion }\end{array}$ & $\begin{array}{c}\text { Community } \\
\text { involve- } \\
\text { ment }\end{array}$ & $\begin{array}{c}\text { Involve- } \\
\text { ment } \\
\text { description }\end{array}$ & $\begin{array}{c}\text { Target } \\
\text { community }\end{array}$ \\
\hline Dei 1993 & Ghana & yes & yes & yes & no & no & - & $\begin{array}{c}\text { Local } \\
\text { population }\end{array}$ \\
\hline Robinson and Ross 1997 & Canada, $\mathrm{AB}$ & yes & yes & yes & yes & $6-7$ & yes & Indigenous \\
\hline Wickramasinghe 1997 & Sri Lanka & yes & yes & yes & $+/-$ & no & - & $\begin{array}{c}\text { Local } \\
\text { population }\end{array}$ \\
\hline Thompson 1999 & Indonesia & yes & no & - & no & yes $^{\mathrm{a}}$ & yes & $\begin{array}{c}\text { Local } \\
\text { population }\end{array}$ \\
\hline Martin and Lemon 2001 & India & yes & no & - & no & 5 & yes & $\begin{array}{c}\text { Local } \\
\text { population }\end{array}$ \\
\hline Gautam and Watanabe 2002 & Nepal & no & - & - & - & no & - & $\begin{array}{c}\text { Local } \\
\text { population }\end{array}$ \\
\hline Klooster 2002 & Mexico & yes & no & - & no & 7 & yes & $\begin{array}{c}\text { Local } \\
\text { population, } \\
\text { metis }\end{array}$ \\
\hline McGregor 2002 & Canada, ON & yes & yes & yes & yes & 4 & yes & Indigenous \\
\hline Natcher and Hickey 2002 & Canada, $\mathrm{AB}$ & yes & yes & yes & yes & 6 & yes & Indigenous \\
\hline Karjala and Dewhurst 2003 & Canada, BC & yes & yes & yes & yes & 6 & yes & Indigenous \\
\hline Parsons and Prest 2003 & Canada & no & - & - & - & economic & yes & Indigenous \\
\hline Ghazanfari et al. 2004 & Iran & yes & yes & yes & yes & ultimately 7 & yes & $\begin{array}{c}\text { Local } \\
\text { population }\end{array}$ \\
\hline Karjala et al. 2004 & Canada, BC & yes & yes & yes & yes & 6 & yes & Indigenous \\
\hline Polansky and Heermans 2004 & Zambia & yes & yes & no & $+/-$ & 3 & no & $\begin{array}{c}\text { Local } \\
\text { population }\end{array}$ \\
\hline Roth 2004 & Thailand & yes & yes & yes & yes & 7 & yes & $\begin{array}{c}\text { Local } \\
\text { population }\end{array}$ \\
\hline Sekhar 2004 & India & yes & yes & no & yes & 5 & yes & $\begin{array}{c}\text { Local } \\
\text { population }\end{array}$ \\
\hline Herrmann 2005 & Chile & yes & yes & yes & no & no & - & Indigenous \\
\hline McCall and Minang 2005 & Cameroon & yes & yes & yes & yes & 4 & yes & $\begin{array}{c}\text { Local } \\
\text { population }\end{array}$ \\
\hline Natcher et al. 2005 & Canada, YK & yes & no & - & no & 7 & yes & Indigenous \\
\hline Robiglio and Mala 2005 & Cameroon & yes & yes & yes & yes & 3 & yes & $\begin{array}{c}\text { Local } \\
\text { population }\end{array}$ \\
\hline Silvano et al. 2005 & Brazil & yes & yes & yes & no & no & - & Farmers \\
\hline
\end{tabular}

aThis article presents a synthesis of different experiments of social forestry, which is impossible to rank using Berkes' (1994) scale.

It is difficult to draw generalities from case studies as they are each at different stages of development; these include: (a) a call to involve local communities (Dei 1993, Wickramasinghe 1997, Gautam and Watanabe 2002, Herrmann 2005), (b) the development of a future participation process (Natcher and Hickey 2002, Ghazanfari et al. 2004), (c) presentation of an active participation process (Natcher et al. 2005), (d) evaluation of an active participation process (Martin and Lemon 2001, Karjala et al. 2004,
Polansky and Heermans 2004, McCall and Minang 2005, Robiglio and Mala 2005, Roth 2004), (e) evaluation of stakeholder satisfaction (McGregor 2002), and (f) a comparison of different approaches that incorporated TEK (Klooster 2002). Furthermore, the autonomy of involved communities and the level of their assimilation into modern ways of life are different. In addition, the ecological, social and political context of each study is specific, including projects of local development using forestry, conservation or restoration projects that are in 
conflict with traditional subsistence gathering, agriculture or agroforestry, together with projects of commercial timber harvesting, which limits indigenous rights.

Levels of co-management (sensu Berkes 1994) by the local community varied considerably among the studies. For example, the case study presented by Polansky and Heermans (2004) and Robiglio and Mala (2005) were at level 3 (co-operation). Robiglio and Mala (2005) presented Cameroon Communal Forests. This kind of land tenure is quite new and the participation process is probably a work in progress. McGregor's (2002) study concluded that to reach stakeholders' satisfaction, a minimal co-management level requires a mutual exchange of information (level 4: communication), but only if the control of methods of knowledge sharing is relinquished to the indigenous community. Herrmann (2006) suggested also, in a second study, the implementation of a process that represents a minimum of level 4 . This level seems to have been attained in another Cameroon Communal Forest (McCall and Minang 2005). The two projects in India reached level 5 (advisory committees), but they were possibly difficult to implement because of differences between the Forest Department and the villagers who depended on trees as a resource (fuelwood, fruits, fodder) (Sekhar 2004). Moreover, Martin and Lemon (2001) explained that these new institutional arrangements often reproduce the social relationships that marginalize certain groups of people, especially women. Processes developed by the different Canadian projects seem to be at level 6 (management board), following Berkes' (1994) scale (Natcher and Hickey 2002, Karjala and Dewhurst 2003, Karjala et al. 2004). Natcher and Hickey (2002) presented a management board composed by five community representatives out of 14 members, along with two others from economic development corporations, but final decisions with regards to forest management remained contingent upon the approval of the Minister of Environmental Protection (level 6). Karjala and Dewhurst (2003) and Karjala et al. (2004) presented the Aboriginal Forest Planning Process, which aims at integrating TEK and western science within a participatory process (using evaluation of management scenarios with different protection levels) in a co-managed research forest (local indigenous community-University of Northern British Columbia). Robinson and Ross (1997) described a parallel consultation process that complements the regular process, providing the community detailed information on annual operating plans, but with no direct participation in their elaboration. Natcher et al. (2005) also presented co-management committees including community representatives, which correspond to level 7 (partnership of equals) on Berkes' scale. Roth (2004) suggested that general information provided by foresters and detailed information of a specific area provided by local traditional knowledge could be merged in order to manage a territory (level 7: partnership of equals). Moreover, he noted the importance of having common ground and developing trust among stakeholders. After this, it is possible to find similarities in the different views to start a process of collaborative management, using negotiations. Ghazanfari et al. (2004) presented a work in progress, which they hope will reach ultimately level 7 . Finally, Klooster (2002) presented a case of strict community control (level 7), with report production and frequent control by community audits in Mexico.

\section{Economic involvement}

Only one paper addressed issues of economical involvement of local communities in the forest sector (Parsons and Prest 2003). Parsons and Prest (2003) proposed possible economic partnerships between local communities and industries: opportunities for employment (in sawmills or in different logging contracts), training programs and joint ventures to build-or save-a mill or a value-added production. This represents a form of involvement but this is not participation per se, thus it could not be translated on a scale of participation like Berkes' (1994).

\section{Discussion}

Enhancing participation: How to facilitate TEK incorporation? Robinson and Ross (1997) judged that the impact of indigenous knowledge on forest management was, with a few exceptions, negligible. This viewpoint was also expressed more recently by Stevenson and Webb $(2003,2004)$, indicating that the situation has not really changed over the past decade. According to these authors, the real contributions of indigenous knowledge to sustainable forest management (SFM) have yet to come. Effective policies, institutions and practices need to be developed in order to fully and equitably incorporate local communities into SFM. TEK integration still entails numerous challenges, given that: 1) TEK is disappearing at a fast pace, given that it is passed through oral tradition that may be lost over time-like language, TEK won't survive unless practised-and the lack of human resources to document it before it is lost; 2) there are practical problems in trying to reconcile two very different worldviews and in translating ideas and concepts from one culture to another; 3 ) there is a problem of attitude that prevents both western scientists and Traditional Peoples from respecting the value of each other's knowledge systems, and among western scientists, between natural and social scientists regarding research methods; and 4) there is a political problem that impedes the development of institutional arrangements that recognize the validity of TEK (Johnson 1992).

To gather TEK, there could be two different approaches: one could involve outsiders (familiarized with community worldview) who could collect traditional knowledge, or, the second could build on local people (familiarized with western science) who possess the knowledge, to transmit it to resource managers. In the first case, numerous methods exist to collect traditional knowledge or community perspectives and values, but not all have the same usefulness for incorporation in resource management. The more global is the understanding of local knowledge the more it could be effectively included in management plans (Ericksen and Woodley 2005). TEK-gathering is often fragmentary, focusing on some specific aspects only. To bypass this problem, researchers usually use more than one approach. The review of methodologies is not exhaustive; for example, rapid appraisal (RRA) and participatory appraisal (PRA) are also largely used. These methods, which allow learning about local conditions in an iterative and expeditious manner, are used in the identification of community problems and for monitoring and evaluation of ongoing activities in different fields (particularly in social and medical sciences; Campbell 2001). In the second case, it is urgent to keep this knowledge alive within traditional communities. There is an unavoidable assimilation of these com- 
munities (due to dramatic cultural changes) and then a failure to transmit traditional knowledge to younger generations (due to trans-generation conflicts and state-defined education; Johnson 1992).

The lack of empowerment of local communities in using their knowledge in resource use decision-making is mainly due to the fact that this knowledge does not easily fit into the western scientific paradigm (Stevenson and Webb 2004). Because of its removal from context and subsequent distortion in translation, traditional knowledge loses part of its essence and becomes coarse information (sanitized knowledge). Moreover, when decisions using this information are taken, the absence of TEK holders and users contribute to increase this phenomenon (Stevenson and Webb 2004). Woodley (2005) developed a conceptual framework for representing traditional ecological knowledge that allows understanding how people relate to their environment, instead of documenting knowledge, which could assist in bridging differences in worldviews and epistemologies between researchers and Traditional Peoples. In her framework, TEK emerges from context (history, demographic factors and biophysical features of the place where they live), practice (action, physical interaction and experiential learning) and belief (influence of spirituality and values on how they act within their environment). If context changes in time or space, a process of "reflexivity" allows more factual knowledge to be adapted in a new context. This process, which is considered part of the resilience and adaptive capacity of the community, may be a means to use TEK in a context of resource management (Woodley 2005).

Despite the fact that the Millennium Ecosystem Assessment initiative developed a general framework for collecting traditional knowledge and for incorporating it in current management purposes, each local committee had to modify and adapt this framework to fit the local context and then obtain the recognition of the community. However, some recommendations were proposed by Ericksen and Woodley (2005) to incorporate multiple knowledge systems. First, TEK-gathering should be done by an interdisciplinary team composed of ecological scientists as well as social scientists (like anthropologists, philosophers of science or community-oriented researchers) to provide full understanding of local knowledge. All members of this team should endorse the interdisciplinary perspective and be ready to spend time working in close collaboration in a continuous way over years. In-depth understanding of local knowledge by outsiders requires skill, training, respectful behaviour, an open and non-judgmental attitude and experience of the place. Secondly, this team should be constantly assisted by a coordination office that acts as a bridge between scientists and users. On the other hand, all sources of information (scientific and traditional) should be critically assessed and validated through a proposed process including triangulation (cross-validation from different sources) and review by the community as well as stakeholders (Ericksen and Woodley 2005). In order to give the same weight to each type of knowledge, Ericksen and Woodley (2005) proposed a cross-validation process in which local experts validate scientific knowledge and scientists validate local knowledge.

The lack of clarity in the definition of objectives that are pursued by government agencies and industries is undoubtedly at the source of some difficulties limiting the incorpora- tion of TEK into forest management (Robinson and Ross 1997). Officially, governments and industries support the principle of integrating TEK into forest management plans and implement consultation processes with native communities affected by timber harvesting, but precise mechanisms are usually lacking. At best, some projects take inspiration from traditional practices or develop new approaches to reduce conflicts between stakeholders (Herrmann 2005). Even though some initiatives have appeared (Jacqmain et al. 2005), it is clear that the integration of these two knowledge systems (i.e., TEK and western science) at a large scale remains a distant goal, because the following conditions must be met: support for the comprehensive documentation of TEK, a recognition of alternative knowledge systems, support for cross-cultural education, and mostly, political recognition of local population claims to land and resources (Johnson 1992).

Between different approaches, the development of land use and occupation maps could also be a good first step to incorporate local population interests and practices, but Natcher (2001) discussed methodological limitations in land use mapping. Among these limitations are financial constraints related to this kind of research, unequal financial support between communities, lack of technical training at the community level to implement locally controlled research, problems of representation of community land use reflecting only one perspective (under-represented factions of the community, like women), problems of "completeness" (a long process, only permitting a small part of the territory to be recorded), and problems of respecting intellectual property rights regarding the information, together with its decontextualization by industry land managers. Moreover, mapping traditional land uses often has failed to recognize the cultural importance of landscapes for Indigenous People, restricting this knowledge to a simple spatial distribution of physical features on the landscape (Natcher 2001). It is the activity per se that is valued by local people more than the particular place where the activity occurs. On the other hand, this mapping is important for establishing legally recognized land tenure and boundaries, and also in providing a common ground to negotiate and develop an acceptable strategy for the different stakeholders (Roth 2004). According to Roth (2004), documenting the spatial organisation of environmental practices will contribute to the understanding of the challenges and possibilities to integrate TEK. Effective integration will pass through an analysis of compatibility and convergence between TEK and science inside each of the four spheres of Berkes' (1999) knowledge-practice-belief complex. Roth (2004) further suggested using spatial tools to facilitate the integration of TEK and science through their similarities. Land use maps also present some limits for both industry and government viewpoints: methodological and technical issues (accuracy of the data), accessibility of the data, unresolved issues regarding land claims, the need for government leadership (in developing appropriate policies), differing expectations and agendas, and the need for a global coordinated system for the conduct of land use studies (MacKinnon et al. 2001).

Some difficulties with incorporating TEK into forest management are easy to solve, while others are more complex. The first step is certainly the official recognition of the usefulness of TEK in forest management. Next, an in-depth understanding of local knowledge through their relationship with their environment could be collected by an interdisciplinary team 
and the establishment of clear procedures to incorporate this information efficiently could be developed, with respect shown to knowledge holders. Because TEK is place-based, processes to incorporate this knowledge also need to be locally developed with the community, even if a general framework could provide a benchmark. Land use maps (to have a spatial common ground of discussion), combined with value maps (to take into account more abstracted concepts and objectives), seem to be positive steps forward in the incorporation of TEK, as long as they are really considered in forest management planning.

\section{How to enhance community involvement in forest planning and management?}

Within the boreal forest of Canada, timber harvest planning is contingent on conflicts between commercial forestry and indigenous ancestral rights to access wildlife resources. Several authors have used processes derived from Stevenson's models (Stevenson and Webb 2003, 2004; Stevenson 2005) to analyze the integration of TEK into forest planning. Stevenson and Webb (2003) first described the current statusquo (Fig. 2a), which revealed recurrent problems (as mentioned in the previous section), unacceptable to the majority. However, local communities are not really involved in the process; at best some of their knowledge is considered. First, only a small part of TEK is included in final forest management decision-making, because a large part is not accessible to managers, through either a lack of will or understanding (Stevenson 1996). Second, the data-gathering process of TEK is problematic, because this knowledge is largely oral, taped, "filtered" by the translation process, transcribed and divorced from its original context, which causes important loss of information throughout the process of data acquisition (Stevenson and Webb 2003). Finally, collected TEK is often sanitized and modelled to match a western vision to make it more useable. Moreover, few considerations are given to knowledge holders (non-respect of intellectual property). When it is collected, knowledge becomes information, which is transcribed, and subsequently, this represents the authority reference, excluding knowledge holders. This process represents the current scientific way of knowledge propagation. Results, when published, become universal knowledge and are no longer possessed by an individual or a group, contrary to registered patent.

Stevenson and Webb (2003) proposed a second model that more efficiently incorporates TEK with a real involvement of knowledge holders in decision-making (Fig. 2b). In this model, TEK is considered in its entirety and is equal to western science. The focus is not on how TEK could inform western science, but on the management approaches and ecological relationships that TEK and western science are intended to produce (Stevenson and Webb 2003). Western science emphasizes ecological components so that managers can provide information and knowledge regarding the assessment and management of valued ecosystem components. On the other hand, First Nations (and many Traditional Peoples) valorize ecological relationships (network between the components) so that local peoples can provide wisdom and knowledge relevant to managing valued ecosystem relationships, particularly human-forest resource relationships. The two visions are complementary (Stevenson and Webb 2004). Currently, management considerations almost always focus

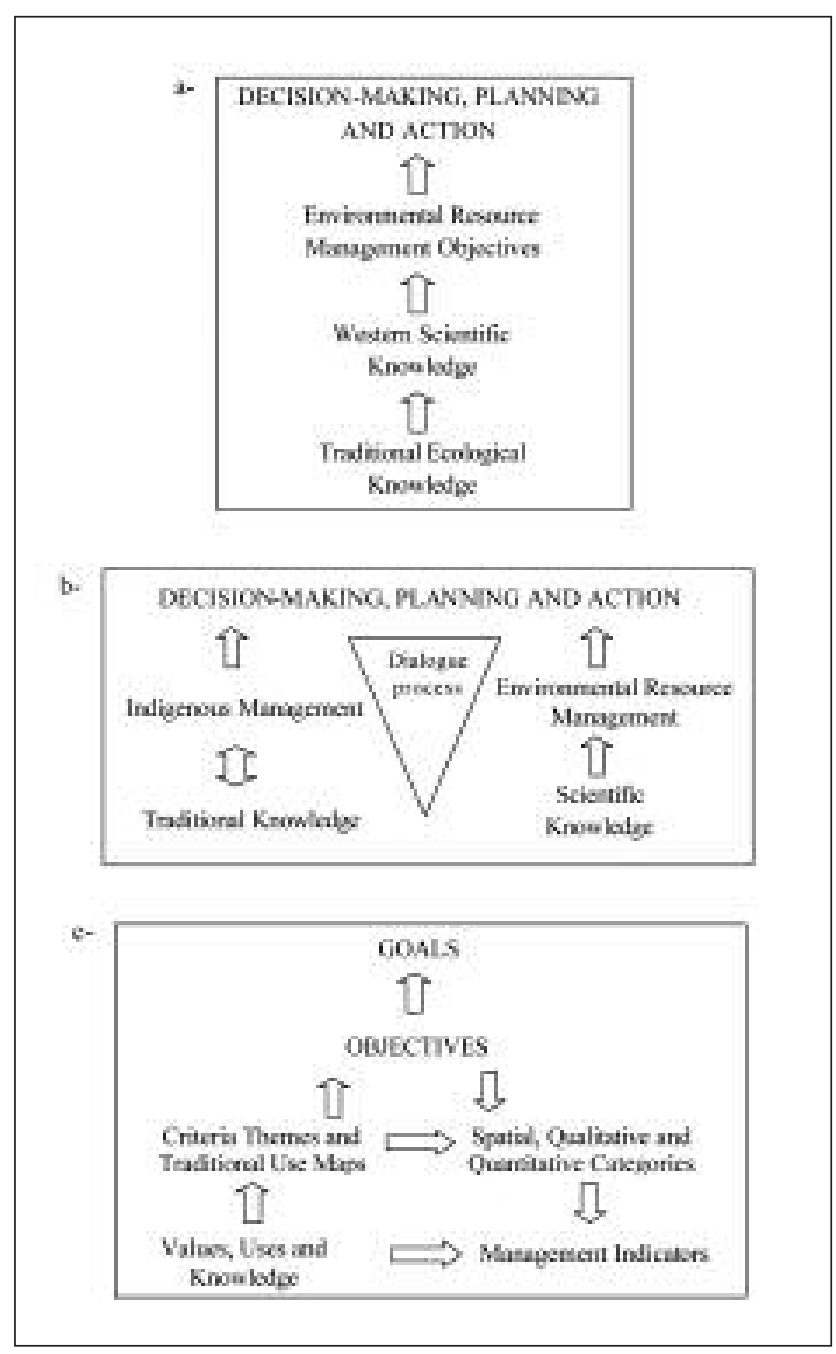

Fig. 2. Models for incorporating TEK in resource management : a) status-quo (from Stevenson and Webb 2003), b) Stevenson's model (modified from Stevenson 2005) and c) Karjala's model (Aboriginal Forest Planning Process framework) (from Karjala et al. 2004).

on information about the resource and exclude knowledge of the relationships. Stevenson and Webb (2003) also presented a process to establish an efficient participatory management in four steps. First, the communities need to document, assess and prioritize their needs, uses and values with respect to the forest and forest resources. Second, communities develop their land use and forestry objectives, plans, policies and regulations. Third, local communities negotiate with government agencies and industries to agree on effective policies, institutions and strategies that will meet their objectives, rights and interests, with respect to the other stakeholders. Finally, an adaptive management approach is required to modify existing policy and practice when required in the future. This means that Traditional Peoples become stakeholders and have the same weight in all steps of forest management decision-making. During such a deliberative process, each stakeholder has to be open and critical about its role, in order to contribute to the establishment of a successful management plan. 
The Waswanipi Cree Model Forest used this approach to build its own action plan. The group proposed a negotiation mechanism for forest management plans with forest companies based on the principle of equality between community representatives and forest companies (Pelletier 2002, Waswanipi Cree Model Forest 2007). The first step documented traditional land use and occupation of the territory. These maps were combined with management objectives and values developed for each season (depending on traditional activities) to develop zoning maps with conservation values to prioritize (Waswanipi Cree Model Forest 2007). In parallel, a diagnosis of the state of the forest was conducted, not only from a forester's perspective but also from the community perspective. For each zone, different management strategies were proposed in a guide to forest companies, who had to produce forest management plans. These plans had to be negotiated until consensus was reached (Pelletier 2002). Some issues were identified during the process, like unequal power between industry and community, communication problems, schedule delays, and management of special issues. The goal was not to move from forestry supremacy with no place for traditional land use to traditional land use supremacy with no place for forestry. This model did not aim at prioritizing community land use while adjusting ad hoc forest harvesting, but intended to give equal weight to the stakeholders in multi-use management of the forest.

A similar model was developed by Karjala and collaborators (Aboriginal Forest Planning Process) based on criteria and indicators that rank community priorities in the first place (Fig. 2c). First, they proposed to develop land use maps. Second, they compiled values, local needs and perspectives depending on people's age-groups. Third, they developed four thematic maps (fishing, hunting-trapping, plant gathering and cultural sites). Finally, they developed a zoning system and completed maps presenting three categories of criteria and indicators (spatial, quantitative and qualitative) (Karjala and Dewhurst 2003, Karjala et al. 2004). The authors have provided a list of problems they encountered throughout the project: lack of human, financial, technical and information resources; mistrust, misuse of information and misunderstandings; difficulty in collecting values and goals without legal and policy provisions; difficulty in identifying important and testable indicators; and lack of power of the community in decision-making.

All these case studies are in the same country and in the same context. Approaches involving local communities were also quite similar and seem to be appreciated by these communities. In all cases, the researchers acted as initiators or at least as mediators (in some countries, it could also be NGOs) among the community, government and industries. This mediation was not obligatory, however, but depended on the context and the capacity of each community. For example, in Thailand, a local community initiated a project of communal forestry (bottom-up project). Despite the fact that community members were highly motivated, legal support was absent, and governmental forest institutions could not transfer appropriate technology to the community. Hence, the scope for developing strategies combining TEK and science is limited, formal institutional arrangements are lacking, and community access to high-level technology is limited (Abdus Salam et al. 2006).

\section{Economic involvement}

Hickey and Nelson (2005) defined four categories of economic partnership to help communities in choosing which is the best adapted to each situation, depending on pursued goals and objectives. These authors presented a Canada-wide survey of economic partnerships between First Nations and forest companies, including local opportunities for employment, training programs and joint ventures. Parsons and Prest (2003) noted an increase in aboriginal people involvement with professional and technical expertise in forestry. However, access to large amounts of capital necessary to build a mill, for example, are not easily available to small communities. Consequently, an association with an existing forest company is often necessary to initiate such projects (Hickey and Nelson 2005). In doing so, local communities can gain control over where and when logging is conducted, but never over how much area is to be harvested, because the annual allowable cut is determined by provincial governments throughout Canada. In some cases, this cause conflicts inside the community, because people feel betrayed even by indigenous forest companies, as well as by non-indigenous ones. Wyatt (2004) drew up the profile of an indigenous forest company in Quebec (Canada), and showed that indigenous workers are often restricted to road construction, planting and thinning jobs while non-indigenous people are mostly employed in harvesting operations. This lack of local professional skills is one of the most important issues for First Nations local communities as well as financial mismanagement. In another context, Mengue-Medou and Waaub (2005) evaluated socio-economic issues and positive/negative impacts of forest exploitation in Gabon, where public participation is quite low. The establishment of a forest company in the region under study created employment, but not as well as expected, again because of the lack of professional skills in the local population. Finally, there were mostly negative social effects for the local community: population increase with unemployment increase, conflict between villagers who need non-timber forest products and industries who want timber, loss of spiritual and cultural practices, loss of ancestral rights, loss of the social structure of power, increase in the prices for essential foods (Mengue-Medou and Waaub 2005).

There is often confusion between two types of involvement of a local community in forest management: economic involvement could in no case replace involvement in forest planning and management. Economic involvement is important in creating jobs and economic development, but community involvement during the planning process has a greater impact in terms of community empowerment, political power, ancestral territory rights recognition and traditional knowledge recognition. These two kinds of involvement are not exclusive, but there typically is a diversity of opinions within communities, i.e., the young could prefer jobs over recognition of territory rights while elders prefer the opposite (Natcher and Hickey 2002). Nevertheless, creating jobs (for example, trained managers and auditors) inside a management institution represents a form of involvement (Klooster 2002) but it is not participation.

\section{Conclusion}

The few attempts at TEK incorporation into forest management could be classified into two categories of results: conflicts between different uses (for example, in the context of 
conflict between commercial forestry and indigenous rights for access to wildlife and non-timber forest products), and conflicts between conservation and traditional or commercial use (for example, in developing countries where deforestation is practised to facilitate agriculture). In all cases, conflicts resulted in the dispossession of ancestral lands by local populations. In the first category, Canadian initiatives seemed to be one of the most advanced in terms of community involvement, with several pilot projects already established (seven of the peer-reviewed papers are from Canada, four from Africa, seven from Asia and three from South America). Similar processes have been proposed, where the aim is greater participation of local communities in forest planning and management. All reviewed processes need a long time to be implemented-to adapt a general framework to the local context, which becomes recognized by the community, and to establish mutual confidence among stakeholders. Incorporating TEK in forest management plans could be done with land use maps where commercial forestry, traditional activities, and integral protection are zoned. With respect to traditional activity seasons or wildlife-associated "seasons" (e.g., reproduction, wintering), these zones need not be necessarily exclusive in time and in space. Concrete trials need to be tested; results, successes and failures have to be communicated in order to improve processes and inform other researchers. Considerable effort will be required to reach a high level of participation of local communities and efficient incorporation of TEK. This may only be accomplished through recognition of alternative knowledge systems, a greater open-mindedness, and support for inter-cultural education (in both directions). Important changes in mentality and firm political decisions (through law, which imposes a participation process, for example) are still required before more efficient partnerships between TEK and western science are reached in forest management planning. Concurrently, it will be important to train local people (community members) who will adopt the process and run it once it is functional and well established.

As already noted by Davis and Wagner (2003), who conducted a review of TEK-gathering methodologies, too many researchers are not reporting critical details of their research designs and methodologies. Moreover, several interesting processes and initiatives were not published in accessible papers for others practitioners. We strongly encourage people (researchers, practitioners and communities) working in TEK-related topics and in traditional community involvement in natural resource management, more specifically forest management, to widely diffuse their research and results in peer-reviewed journals worldwide as the end result of any scientific process. A larger diffusion of studies would allow others working in the same domain to benefit from successes and errors made elsewhere. Secondly, this would contribute to increase recognition of TEK value for scientists and practitioners, and hence break down misunderstandings and ignorance related to TEK. As Davis and Wagner (2003) have advocated, it is time to move beyond current preoccupations with regards to theoretical issues and general endorsements of the value of traditional ecological knowledge, and begin the search of processes to document traditional ecological knowledge that efficiently involves local communities, and finally, to diffuse these processes in published and accessible papers.

\section{Acknowledgements}

M. Cheveau benefited from a National Sciences and Engineering Research Council of Canada graduate scholarship during the preparation of this review, as well as a graduate scholarship from the Fondation de la Faune du Québec. Thoughtful comments from L. Lepage and C. Samson greatly contributed to improve an earlier version of this manuscript. The authors also thank W. Parsons for revision of the English language, D. Martinez and two anonymous reviewers who gave useful comments to improve the final paper.

\section{References}

Abdus Salam, M.D., T. Nogushi and R. Pothitan. 2006. Community forest management in Thailand: current situation and dynamics in the context of sustainable development. New Forests 31: 273-291.

Baines, G. and E. Hviding. 1993. Traditional environmental knowledge for resource management in Marovo, Solomon Islands. In N.M. Williams and G. Baines (eds.). Traditional ecological knowledge: wisdom for sustainable development. pp. 56-65. Centre for Resource and Environmental Studies, Australian National University, Canberra, Australia.

Berkes, F. 1993. Traditional ecological knowledge in perspective. In J.T. Inglis (ed.). Traditional ecological knowledge: concepts and cases. pp. 1-9. International Program on Traditional Ecological Knowledge and International Development Research Centre, Ottawa, ON.

Berkes, F. 1994. Co-management: bridging the two solitudes. Northern Perspectives 22(2-3): 18-20.

Berkes, F. 1999. Sacred ecology: traditional ecological knowledge and resource management. Taylor and Francis, Philadelphia, PA. 209 p.

Berkes, F., J. Colding and C. Folke. 2000. Rediscovery of traditional ecological knowledge as adaptive management. Ecology 10(5): 1251-1262.

Campbell, J.R. 2001. Participatory rural appraisal as qualitative research: Distinguishing methodological issues from participatory claims. Human Organization 60(4): 380-389.

Canadian Council for Forest Ministers (CCFM). 2000. Criteria and indicators of sustainable forest management in Canada: National status 2000. Natural Resources Canada, Canadian Forest Service, Ottawa, ON. 124 p.

Dahl, F. 2005. Distinct seasonal habitat selection by annually sedentary mountain hares (Lepus timidus) in the boreal forest of Sweden. European Journal of Wildlife Research 51(3): 163-169.

Davidson-Hunt, I. and F. Berkes. 2001. Changing resource management paradigms, traditional ecological knowledge, and non-timber forest products. In I. Davidson-Hunt, L.C. Duchesne and J.C. Zasada. Forest communities in the third Millennium: linking research, business and policy towards a sustainable non-timber forest product sector. pp. 78-92. USDA Forest Service, St. Paul, MN.

Davis, A. and J.R. Wagner. 2003. Who knows? On the importance of identifying "experts" when researching local ecological knowledge. Human Ecology 31(3): 463-489.

Dei, G.J.S. 1993. Indigenous African knowledge systems: local traditions of sustainable forestry. Singapore Journal of Tropical Geography 14(1): 28-41.

Ericksen, P. and E. Woodley. 2005. Using multiple knowledge systems: Benefits and challenges. Chapter 5. In D. Capistrano, C.K. Samper, M.J. Lee and C. Raudsepp-Hearne (eds.). Ecosystems and human well-being: Multiscale assessments. pp.85-117. Findings of the Sub-Global Assessments Working Group. Volume 4. Millennium Ecosystem Assessment Series. Island Press.

Feit, H.A., 1988. Self-management and state-management: forms of knowing and managing northern wildlife. In M.M.R. Freeman and L. N. Carbyn. Traditional knowledge and renewable resource man- 
agement in Northern regions. pp. 65-71. IUCN Commission on Ecology and the Boreal Institute for Northern Studies. Occasional Publication Number 23.

Gautam, K.H. and T. Watanabe. 2002. Silviculture for non-timber forest product management: challenges and opportunities for sustainable forest management. The Forestry Chronicle 78(6): 830-832. Ghazanfari, H., M. Namiramian, H. Sobhani and R.M. Mohajer. 2004. Traditional forest management and its application to encourage public participation for sustainable forest management in the northern Zagros Mountains of Kurdistan Province, Iran. Scandinavian Journal of Forest Research 19 (Suppl.4): 65-71.

Herrmann, T.M. 2005. Knowledge, values, uses and management of the Araucaria araucana forest by the indigenous Mapuche Pewenche people: a basis for collaborative natural resource management in southern Chile. Natural Resources Forum 29(2): 120-134.

Herrmann, T.M. 2006. Indigenous knowledge and management of Araucaria araucana forest in the Chilean Andes: implications for native forest conservation. Biodiversity and Conservation 15: 647-662.

Hickey, C.G. and M. Nelson. 2005. Partnerships between First Nations and the forest sector: a national survey. Sustainable Forest Management Network, Edmonton, AB. 30 p.

Holling, C.S. 1986. The resilience of terrestrial ecosystem: local surprise and global change. In W.C. Clark and R.E.E. Munn. Sustainable development of the biosphere. pp. 292-317. Cambridge University Press, Cambridge, UK.

Holling, C.S., F. Berkes and C. Folke. 1998. Science, sustainability and resource management. In F. Berkes and C.E. Folke. Linking social and ecological systems for resilience and sustainability. pp. 342-362. Cambridge University Press, Cambridge, UK.

Howard, A. and F. Widdowson. 1996. Traditional knowledge threatens environmental assessment. Policy Options 17(9): 34-36.

Hunter, M.L.J. 1999. Maintaining biodiversity in forest ecosystems. Cambridge University Press. U.K. 698 p.

Jacqmain, H., L. Bélanger, R. Courtois, T. Beckley, S. Nadeau, C. Dussault and L. Bouthillier. 2005. Proposal to combine Cree and scientific knowledge for improved moose habitat management on Waswanipi Eeyou Astchee, northern Québec. Alces 41: 147-160.

Johnson, M. 1992. LORE: Capturing traditional environmental knowledge. International Development Research Centre (IDRC), Ottawa, ON. 190 p.

Joshi, L., L. Arévalo, N. Luque, J. Alegre and F. Sinclair. 2004. Local ecological knowledge in natural resource management. In Proceedings, Bridging scales and epistemologies: Linking local knowledge and global science in multi-scale assessments, Alexandria, Egypt, March 17-20, 2004.

Karjala, M.K. and S.M. Dewhurst. 2003. Including aboriginal issues in forest planning: a case study in central interior British Columbia, Canada. Landscape and Urban Planning 64: 1-17.

Karjala, M.K., E.E. Sherry and S.M. Dewhurst. 2004. Criteria and indicators for sustainable forest planning: a framework for recording Aboriginal resource and social values. Forest Policy and Economics 6: 95-110.

Klooster, D.J. 2002. Toward adaptive community forest management: Integrating local forest knowledge with scientific forestry. Economic Geography 78(1): 43-70.

Kovacs, J.M., J. Malczewski and F. Flores-Verdugo. 2004. Examining local ecological knowledge of hurricane impacts in a mangrove forest using an analytical hierarchy process (AHP) approach. Journal of Coastal Research 20(30): 792-800.

Lewis, H.T. 1993. Traditional ecological knowledge: some definitions. In N.M. Williams and G. Baines. Traditional ecological knowledge: wisdom for sustainable development. pp. 8-12. Centre for Resource and Environmental Studies, Australian National University, Canberra, Australia.

MacKinnon, L., C. Apentiik and M.P. Robinson. 2001. Revisiting traditional land use and occupancy studies: relevance and implications for resource management in Alberta. The Forestry Chronicle 77(3): 479-489.
Martin, A. and M. Lemon. 2001. Challenges for participatory institutions: the case of village forest committees in Karnataka, South India. Society and Natural Resources 14(7): 585-597.

McCall, M.K. and P.A. Minang. 2005. Assessing participatory GIS for community-based natural resource management: claiming community forests in Cameroon. The Geographical Journal 117(4): 340-356.

McGregor, D. 2002. Indigenous knowledge in sustainable forest management: community-based approaches achieve greater success. The Forestry Chronicle 78(6): 833-836.

Mengue-Medou, C. and J.P. Waaub. 2005. Évaluation des impacts socio-économiques: cas d'une unité forestière d'aménagement de la compagnie forestière Leroy-Gabon. VertigO 6(2): 183-190.

Natcher, D.C. 2001. Land use research and the duty to consult: a misrepresentation of the aboriginal landscapes. Land Use Policy 18(2): 113-122.

Natcher, D.C. and C.G. Hickey. 2002. Putting the community back into community-based resource management: a criteria and indicators approach to sustainability. Human Organization 61(4): 350-363. Natcher, D.C., S. Davis and C.G. Hickey. 2005. Co-management: managing relationships, not resources. Human Organization 64(3): 240-250.

National Forest Strategy Coalition. 2003. National forest strategy 2003-2008: toward the sustainable forest - the Canadian commitment. Natural Resources Canada, Canadian Forest Service, Ottawa, ON. 74 p.

Pakia, M. and J.A. Cooke. 2003a. The ethnobotany of the Midzichenda tribes of the coastal forest areas in Kenya: 1. General perspective and non-medicinal plant uses. South African Journal of Botany 69(3): 370-381.

Pakia, M. and J.A. Cooke. 2003b. The ethnobotany of the Midzichenda tribes of the coastal forest areas in Kenya: 2. Medicinal plant uses. South African Journal of Botany 69(3): 382-395.

Parsons, R. and G. Prest. 2003. Aboriginal forestry in Canada. The Forestry Chronicle 79(4): 779-784.

Pelletier, M. 2002. Enhancing Cree participation by improving the forest management planning process. Waswanipi Cree Model Forest. Waswanipi, Québec, QC. 28 p.

Poissonnet, M. and G. Lescuyer. 2005. Aménagement forestier et participation: quelles leçons tirer des forêts communales du Cameroun? VertigO 6(2): 109-114.

Polansky, C. and J. Heermans. 2004. Developing forest management plans with high-tech tools and traditional knowledge in Zambia. Journal of Forestry 102(5): 46-51.

Regier, H.A. 1993. The notion of natural and cultural integrity. In S. Woodley, J. Kay and G. Francis (eds.). Ecological integrity and the management of ecosystems. pp. 3-18. St. Lucie Press. Sponsored by Heritage Resources Centre, University of Waterloo, and Canadian Parks Service, Ottawa, ON.

Robiglio, V. and W.A. Mala. 2005. Integrating local and expert knowledge using participatory mapping and GIS to implement integrated forest management options in Akok, Cameroon. The Forestry Chronicle 81(3): 392-397.

Robinson, M.P. and M.M. Ross. 1997. Traditional land use and occupancy studies and their impact on forest planning and management in Alberta. The Forestry Chronicle 73(5): 596-605.

Roth, R. 2004. Spatial organization of environmental knowledge: conservation conflicts in the inhabited forest of northern Thailand. Ecology and Society 9(3): 5 (online).

Sekhar, N.U. 2004. Local versus expert knowledge in forest management in a semi-arid part of India. Land Degradation and Development 15(2): 133-142.

Silvano, R.A.M., S. Udvardy, M. Ceroni and J. Farley. 2005. An ecological integrity assessment of a Brazilian Atlantic Forest watershed based on surveys of stream health and local farmers' perceptions: implications for management. Ecological Economics 53(3): 369-385.

Stevenson, M.G. 1996. Indigenous knowledge in environmental assessment. Arctic 49(3): 278-291. 
Stevenson, M.G. 1997. Ignorance and prejudice threaten environmental assessment. Policy Options 18(2): 25-28.

Stevenson, M.G. 2005. Traditional knowledge and sustainable forest management. Sustainable Forest Management Network, Edmonton, AB. 18 p.

Stevenson, M.G. and J. Webb. 2003. Just another stakeholder? First Nations and sustainable forest management in Canada's boreal forest. In P.J. Burton, C. Messier, D.W. Smith and W.L. Adamovicz. Towards sustainable management of the boreal forest. pp. 65-112. NRC Research Press, Ottawa, ON.

Stevenson, M.G. and J. Webb. 2004. First Nations: measures and monitors of boreal forest biodiversity. Ecological Bulletins 51: 83-92.

Thompson, H. 1999. Social forestry: An analysis of Indonesian forestry policy. Journal of Contemporary Asia 29(2): 187-201.

United Nations Conference on Environment and Development (UNCED). 1992. Rio Declaration on Environment and Development. Principle 22. United Nations, New York, NY.

United Nations World Commission on Environment and Development (UNWCED). 1987. Our common future. Oxford University Press, London, UK. 416 p.
Waswanipi Cree Model Forest. 2007. Ndoho Istchee: an innovative approach to aboriginal participation in forest management planning. Waswanipi Cree Model Forest. Waswanipi, QC. 146 p.

Wickramasinghe, A. 1997. Anthropogenic factors and forest management in Sri Lanka. Applied Geography 17(2): 87-110.

Woodley, E. 2005. Indigenous knowledge: A conceptual framework and a case from Solomon Islands. Chapter 8. In J. Gonsalves, ${ }^{\circ} \mathrm{T}$. Becker, A. Braun, D. Campilan, H. De Chavez, E. Fajber, M. Kapiriri, J. Rivaca-Caminade and R. Vernooy (eds.). Participatory research and development for sustainable agriculture and natural resource management: A sourcebook. Volume 1: Understanding participatory research and development. pp. 65-74. International Potato Center-Users' Perspectives With Agricultural Research and Development, Laguna, Philippines and International Development Research Centre. Ottawa, ON.

Wyatt, S. 2004. Co-existence of Atikamekw and industrial forestry paradigms: occupation and management of forestlands in the StMaurice river basin, Québec. Ph.D. Thesis, Université Laval, Québec, QC. 385 p. 